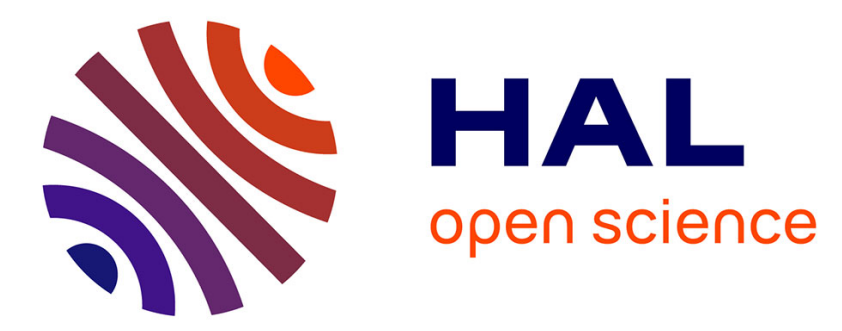

\title{
In-Situ Study of Thermal Comfort Enhancement in a Renovated Building Equipped with Phase Change Material Wallboard
}

\author{
F. Kuznik, J. Virgone, K. Johannes
}

\section{- To cite this version:}

F. Kuznik, J. Virgone, K. Johannes. In-Situ Study of Thermal Comfort Enhancement in a Renovated Building Equipped with Phase Change Material Wallboard. Renewable Energy, 2011, 36 (5), pp.14581462. 10.1016/j.renene.2010.11.008 . hal-00683878

\section{HAL Id: hal-00683878 https://hal.science/hal-00683878}

Submitted on 9 Jun 2014

HAL is a multi-disciplinary open access archive for the deposit and dissemination of scientific research documents, whether they are published or not. The documents may come from teaching and research institutions in France or abroad, or from public or private research centers.
L'archive ouverte pluridisciplinaire HAL, est destinée au dépôt et à la diffusion de documents scientifiques de niveau recherche, publiés ou non, émanant des établissements d'enseignement et de recherche français ou étrangers, des laboratoires publics ou privés. 


\title{
In-Situ Study of Thermal Comfort Enhancement in a Building Equipped with Phase Change Material Wallboard
}

\author{
Frédéric Kuznik ${ }^{\mathrm{a}, *}$, Joseph Virgone ${ }^{\mathrm{a}}$, Kevyn Johannes ${ }^{\mathrm{a}}$ \\ ${ }^{a}$ Université de Lyon, CNRS \\ INSA-Lyon, CETHIL, UMR5008, F-69621, Villeurbanne, France \\ Université Lyon 1, F-69622, France
}

\begin{abstract}
In order to really assess the potential of Phase Change Material (PCM) wallboards, a renovated office building has been monitored during approximatively one year. A room was equipped with PCM wallboards in the lateral walls and in the ceiling. Another room, identical to the first one, was not equipped but also monitored. This study is the first one dealing with the results obtained in real use conditions. Some relevant results of this monitoring are presented in order to understand the physical phenomena involved in the walls storage process. The results show that the PCM wallboards enhance the thermal comfort of occupants due to air temperature and radiative effects of the walls.
\end{abstract}

Keywords: Thermal Energy Storage, Phase Change Material, In-situ Monitoring, Renovated Building.

\footnotetext{
*Corresponding author. Tel.: +33-472-438-461; Fax: +33-472-438-522
}

Email address: frederic.kuznik@insa-lyon.fr (Frédéric Kuznik) 


\section{Introduction}

Nowadays, thermal energy storage systems are essential for reducing dependency on fossil fuels and then contributing to a more efficient environmentally benign energy use [1]. As demand in thermal comfort of buildings rise increasingly, the energy consumption is correspondingly increasing. For example, in France, the energy consumption of buildings has increased by $30 \%$ the last 30 years. Housing and tertiary buildings are responsible for the consumption of approximatively $46 \%$ of all energies and approximatively $19 \%$ of the total $\mathrm{CO}_{2}$ emissions [2]. New buildings represent about $1 \%$ per year of the total amount of buildings, which means that the key to decrease

rapidly $\mathrm{CO}_{2}$ emissions is renovated buildings. The purpose of this study is the use of Phase Change Materials (PCM) for the renovation of light weight buildings like tertiary buildings.

Thermal energy storage can be accomplished either by using sensible heat storage or latent heat storage. Sensible heat storage has been used for centuries by builders to store/release passively thermal energy, but a much larger volume of material is required to store the same amount of energy in comparison to latent heat storage. The principle of the phase change material $(\mathrm{PCM})$ use is simple. As the temperature increases, the material changes phase from solid to liquid. The reaction being endothermic, the PCM absorbs heat. Similarly, when the temperature decreases, the material changes phase from liquid to solid. The reaction being exothermic, the PCM desorbs heat.

The main disadvantage of light weight buildings is their low thermal mass. Obviously, they tend to large temperature fluctuations due to external cool- 
ing, solar heat or internal loads. Using PCM material in such building walls can decrease the temperature fluctuations, particularly in case of solar radiations loads. It is then a potential method for reducing energy consumption in passively designed buildings. This tendency is confirmed by numerous papers available in the literature during the last 20 years. For a review, see in [3], [4], [5] and [6]. Most of the studies in the literature deals with either numerical modeling (for example [7])or laboratory experiments (for example [8]) in order to effectively asses the use of PCM in walls. In this paper, an in-situ monitoring is proposed, in a real renovated tertiary building, in order to really estimate the potential of PCM.

The PCM tested is presented in the part 2 of the paper, and in particular the storage capacity of the material. The part 3 deals with the presentation of the renovated building and the way the PCM is integrated in the envelop. The measurements are also described. The analysis concern three different periods of the monitored years: in section 4, a typical week-end is described in order to understand the physical phenomena involved in the storage/release process, in section 5 a non effective storage week-end is presented and in section 6 the entire monitored period is analyzed.

\section{Composite PCM wallboard tested}

The product tested, ENERGAIN ${ }^{\circledR}$ has been achieved by the Dupont de Nemours Society and is constituted of $60 \%$ of microencapsulated paraffin within a copolymer. The final form of the composite PCM (see figure 1) is a flexible sheet of $5 \mathrm{~mm}$ thickness which density is about $900 \mathrm{~kg} \cdot \mathrm{m}^{-3}$. The thickness of the PCM is the result of a commercial compromise and allows 
$77 \%$ of optimal efficiency obtained with $1 \mathrm{~cm}$ thickness [9].

The thermal conductivity has been measured using guarded hot-plate apparatus [10]. The thermal conductivity is $0.22 \mathrm{~W} \cdot \mathrm{m}^{-1} \cdot K^{-1}$ in liquid phase and decreases to about $0.18 W \cdot m^{-1} \cdot K^{-1}$ in solid phase.

The composite PCM enthalpy has been measured using a differential scanning calorimeter (DSC) as illustrated in figure 2; the heating and cooling rate being $0.05 \mathrm{Kmn}^{-1}$. The thermal analysis is presented for the range $\left[-20^{\circ} \mathrm{C} ; 35^{\circ} \mathrm{C}\right]$. Two curves are presented: the freezing curve (cooling from $35^{\circ} \mathrm{C}$ to $-20^{\circ} \mathrm{C}$ ) and the melting curve (heating from $-20^{\circ} \mathrm{C}$ to $35^{\circ} \mathrm{C}$ ).

From the DSC curves, melting and freezing temperatures are $13.6^{\circ} \mathrm{C}$ and $23.5^{\circ} \mathrm{C}$ respectively. The measured latent heats of melting and freezing are respectively $107.5 \mathrm{~J} / \mathrm{g}$ and $104.5 \mathrm{~J} / \mathrm{g}$; and $72.4 \mathrm{~J} / \mathrm{g}$ and $71 \mathrm{~J} / \mathrm{g}$ for the range $\left[5^{\circ} \mathrm{C} ; 30^{\circ} \mathrm{C}\right]$. The composite PCM described in this article has an important potential of thermal energy storage in building walls. This particularity is due to the possibility to incorporate much more PCM in the polymeric material than in a traditional construction material, for example:

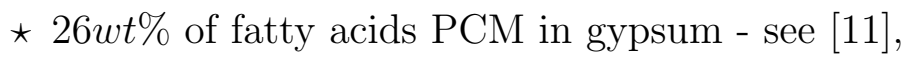

$\star 35 w t \%$ of paraffin in gypsum - see [12],

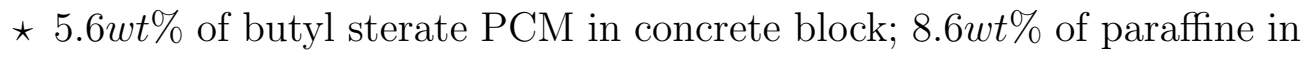
concrete block - see [13].

Considering a temperature variation between $18^{\circ} \mathrm{C}$ and $26^{\circ} \mathrm{C}$, variation that is very common in low inertia building, the PCM stores about 3 times more energy than water and 6 times more energy than concrete (figure 3 ) for the same wall thickness. 


\section{Presentation of the renovated building}

The case studied is a tertiary building, named HELIOS, located in the south of Lyon (France). This building is a light weight construction having significant internal loads and then tends to large temperature fluctuations.

Two joint offices with identical geometries are monitored in this study (figure 4). The air temperatures, the surface temperatures and internal walls temperatures are measured using PT1000 sensors with an accuracy of $\pm 0.6^{\circ} \mathrm{C}$. Only one office is equipped with PCM wallboard included in the lateral partitions and in the false ceiling.

A meteorological station is also installed on this site to measure the solar radiation on the facade of the office rooms and the outside temperature.

The PCM is positioned immediately behind the plasterboard, which is used as external coating. All PCM area approximately represents $46 \mathrm{~m}^{2}$ for a volume office of $50 \mathrm{~m}^{3}$. So one can consider a ratio between the PCM area and the room volume close to 1 in this case. The composition of the walls is given in table 1.

Each wall and the ceiling are equipped with 4 temperature sensors ( $\mathrm{Pt}$ 1000 sensors with an accuracy of $\pm 0.6^{\circ} \mathrm{C}$ ) located at the different layers interfaces. The different channels of the multimeter/multiplexer system (about 50) are scrutinized every 10 minutes and the data are collected via a modem from the laboratory situated at about $10 \mathrm{~km}$ from the experimental site (figure 5).

The period between February 2007 and December 2007 has been studied. As far as the building is occupied and it is very difficult to know exactly the occupancy variation and internal loads, only the results over week-ends are 
presented in this study. The interest is that the conditions are the same. Furthermore, we asked the two occupants of the offices to have the same behavior during the week-end: stop heating or cooling systems, close or not close the blinds. During occupancy, heating or cooling systems are controlled by the occupant of the office room according to his own comfort. Electric convectors are used for heating and fan-convectors with cold water for cooling.

\section{Experimental results for the week-end of November $17^{\text {th }} / 18^{\text {th }}$ 2007}

The first set of experimental data analyzed concerns one week end of November for the days $17^{\text {th }}$ and $18^{\text {th }} 2007$. During this period, there is no workers. The objective of this first set of data analysis is to explain the

physical phenomena involved in the enhancement of thermal comfort in the tested rooms.

\subsection{Office air temperature}

The figure 6 shows the evolution of the air temperature in the two tested rooms. The maximum temperature of the room with PCM is lower than the maximum temperature of the room without PCM of about $2.2^{\circ} \mathrm{C}$. This temperature difference can only be explained because of the PCM integrated in the building walls. In order to explain the physical phenomena involved during this period, the wall surface temperature are examined in detail in section 4.2 . 


\subsection{Walls surface temperatures}

The figure 7 shows the walls, ceiling and air surface temperatures for the office without PCM i.e. the normal renovation. The ceiling temperature varies similarly to the internal temperature because of the low building inertia and then does not contribute to refresh the air. At the opposite, the two lateral partitions, having a good thermal inertia, can contribute to refresh the air because of their temperature lower than the air temperature during the day.

The figure 8 shows the walls, ceiling and air temperatures for the office with PCM i.e. the enhanced renovation. The liquidus and solidus lines represent the position of the melting and freezing temperatures. The vertical wall and ceiling temperatures vary between these two lines meaning that the PCM is both solid and liquid. In this case, the PCM absorbs and releases heat depending on the increasing or decreasing wall temperature. Of course, the effect of PCM can be reinforced if the temperature minimum is lower than $13.6^{\circ} \mathrm{C}$.

\subsection{Thermal comfort}

The thermal comfort of the occupant can be evaluated using various parameters. Of course, one of the main parameter is the air temperature and then the convective heat transfer between the body and the air. The radiative heat transfer between human body and wall surfaces is also important for the thermal comfort of a person. In order to evaluate the effect of PCM on this last heat transfer process, the equivalent globe temperature $T_{g}$ is used. The equivalent globe temperature $T_{g}$ is calculated using the air $T_{a}$ and the mean radiant temperature $T_{r}$. 
The mean radiant temperature $T_{r}$ can be calculated using a simple surface prorate pondering. The air temperature and the radiant temperature have an effect on the globe temperature by the mean of convective and radiative heat transfer respectively. Consequently, the convective and radiative heat transfer coefficient have also an effect.

The globe temperature is evaluated using relation 1. For this relation, the radiative heat transfer prevails on the convective heat transfer in closed enclosures:

$$
T_{g}=0.45 T_{a}+0.55 T_{r}
$$

The figure 9 shows the evolution of the globe temperature for the two offices with and without PCM. The globe temperature is effectively affected by the cooling effect of the surface temperatures. For the PCM office, the effect of the surface cooling is a little more important than without PCM.

The globe temperature is about $3{ }^{\circ} \mathrm{C}$ lower than the air one. The maximum globe temperature is reached after about one hour after the maximum air temperature.

\section{Experimental results for the week-end of March $28^{\text {th }} / 29^{\text {th }} 2007$}

The week-end of March $28^{\text {th }} / 29^{\text {th }} 2007$ is a very interesting example from a storage analysis point of view. The figure 10 shows the week-end of March $28^{\text {th }} / 29^{\text {th }}$ for which the temperature of the rooms rises to about $40^{\circ} \mathrm{C}$. In

such conditions, the PCM is completely in the liquid phase and there is no latent storage effect in the wallboard. 


\section{Experimental results for the period between February and De- cember 2007}

In order to really assess the PCM use for renovated buildings, this section of the article deals with the analyze of the results for the period between February and December 2007. The analyze deals with the globe temperature to take into account the air temperature and the thermal comfort enhancement due to the walls surface temperature.

From the data in the period considered, the number of hours for which the globe temperature is above $29^{\circ} \mathrm{C}$ is an indicator of the comfort enhancement of the PCM use. The difference between the room with PCM and the room without PCM is about 98hours.

\section{Conclusions}

The objective of the paper is the assessment of PCM wallboard use for the renovation of a tertiary (i.e. light weight) building. For that purpose, two identical rooms of a renovated tertiary building have been tested, one equipped with PCM wallboard the other being "classically" renovated. The two rooms and the exterior conditions have been monitored during the 2007 year.

The PCM wallboard are really efficient if the air temperature (and by extension the wall surface temperature) is varying in the melting and freezing temperatures.

The case described in this paper shows a real enhancement of the thermal comfort of occupants. The thermal comfort is enhanced due to both the air temperature and the walls surface temperature. Of course, this improvement 
can only be efficient if the building before renovation is of low inertia and if the temperature variations are around the phase change temperature of the PCM. In our case, the partitions and the floor have a correct thermal inertia in the initial building, and it is only the ceiling inertia improvement that has a clear effect. A more important effect would be observed if the initial building would be of lower inertia.

\section{References}

[1] I. Dincer, M. Rosen, Thermal Energy Storage - Systems and Applications, Jhon Wiley and Sons, 2002.

[2] Climate plan 2004: let's act together to challenge of climate change, Tech. rep., French Ministry of Ecology and Sustainable Developpment (2004).

[3] V. V. Tyagi, D. Buddhi, Pcm thermal storage in buildings: A state of art, Renewable and Sustainable Energy Reviews 11 (6) (2007) 1146 1166.

[4] A. M. Khudhair, M. M. Farid, A review on energy conservation in building applications with thermal storage by latent heat using phase change materials, Energy Conversion and Management 45 (2) (2004) 263 - 275.

[5] Y. Zhang, G. Zhou, K. Lin, Q. Zhang, H. Di, Application of latent heat thermal energy storage in buildings: State-of-the-art and outlook, Building and Environment 42 (6) (2007) 2197 - 2209. 
[6] F. Kuznik, J. Virgone, J.-J. Roux, Energetic efficiency of room wall containing pcm wallboard: A full-scale experimental investigation, Energy and Buildings 40 (2) (2008) 148 - 156.

[7] F. Kuznik, J. Virgone, Experimental investigation of wallboard containing phase change material: Data for validation of numerical modeling, Energy and Buildings 41 (5) (2009) $561-570$.

[8] F. Kuznik, J. Virgone, Experimental assessment of a phase change material for wall building use, Applied Energy 86 (10) (2009) 2038 - 2046.

[9] F. Kuznik, J. Virgone, J. Noel, Optimization of a phase change material wallboard for building use, Applied Thermal Engineering 28 (11-12) (2008) $1291-1298$.

[10] ASTM, Standard test method for steady-state heat flux measurements and thermal transmission properties by means of the guarded-hot-plate apparatus- norm c177 (2004).

[11] L. Shilei, Z. Neng, F. Guohui, Impact of phase change wall room on indoor thermal environment in winter, Energy and Buildings 38 (1) (2006) $18-24$.

[12] S. Scalat, D. Banu, D. Hawes, J. Parish, F. Haghighata, D. Feldman, Full scale thermal testing of latent heat storage in wallboard, Solar Energy Materials and Solar Cells 44 (1) (1996) 49 - 61.

[13] T. Lee, D. W. Hawes, D. Banu, D. Feldman, Control aspects of latent heat storage and recovery in concrete, Solar Energy Materials and Solar Cells 62 (3) (2000) $217-237$. 


\section{List of Tables}

1 Composition of the walls. . . . . . . . . . . . 13 
Wall

Layers

1. Gypsum: $1.3 \mathrm{~cm}$

South façade

2. Insulation: $6 \mathrm{~cm}$

3. glass/aluminium $1 \mathrm{~cm}$

South window Double glazing 4/12/4

1. Gypsum: $1.3 \mathrm{~cm}$

Ceiling

2. Insulation: $10 \mathrm{~cm}$

3. Air gap: $5 \mathrm{~cm}$

4. Steel panel

1. Concrete slab: $16 \mathrm{~cm}$

Floor

2. Air gap: $5 \mathrm{~cm}$

3. Gypsum: $1.3 \mathrm{~cm}$

Existent partition between offices

Partition with corridor

Gypsum: $5 \mathrm{~cm}$

1. Simple glass: $1 \mathrm{~cm}$

Table 1: Composition of the walls. 


\section{List of Figures}

1 Dupont de Nemours PCM composite wallboard. . . . . . . . . 15

2 Differential scanning calorimeter melting and freezing curves for the composite PCM. . . . . . . . . . . . . . 16

3 Comparative values storage capacity of building materials in the same conditions of temperature variation and of thickness. 17

4 View of the Helios building and the two adjacent monitored rooms. . . . . . . . . . . . . . . . . 18

5 The monitoring system: the acquisition data modules and the monitoring screen. . . . . . . . . . . . . . . 19

6 Week-end of November $17^{\text {th }} / 18^{\text {th }} 2007$. We observe the efficiency of the PCM during day period. Heating system has been stopped during this week-end. . . . . . . . . . . . 20

7 Week-end of November $17^{\text {th }} / 18^{\text {th }}$ 2007. Walls, ceiling and air temperatures for the room without PCM. . . . . . . . . . 21

8 Week-end of November $17^{\text {th }} / 18^{\text {th }}$ 2007. Walls, ceiling and air temperatures for the room with PCM. . . . . . . . . . . 22

$9 \quad T_{a}$ and $T_{g}$ evolution on November 17. . . . . . . . . . . 23

10 Week-end of March $28^{\text {th }} / 29^{\text {th }}$ 2007. A temperature higher than the freezing temperature is observed and the PCM is not efficient. Heating and cooling systems are off during this mid-season period. . . . . . . . . . . . . . 24 


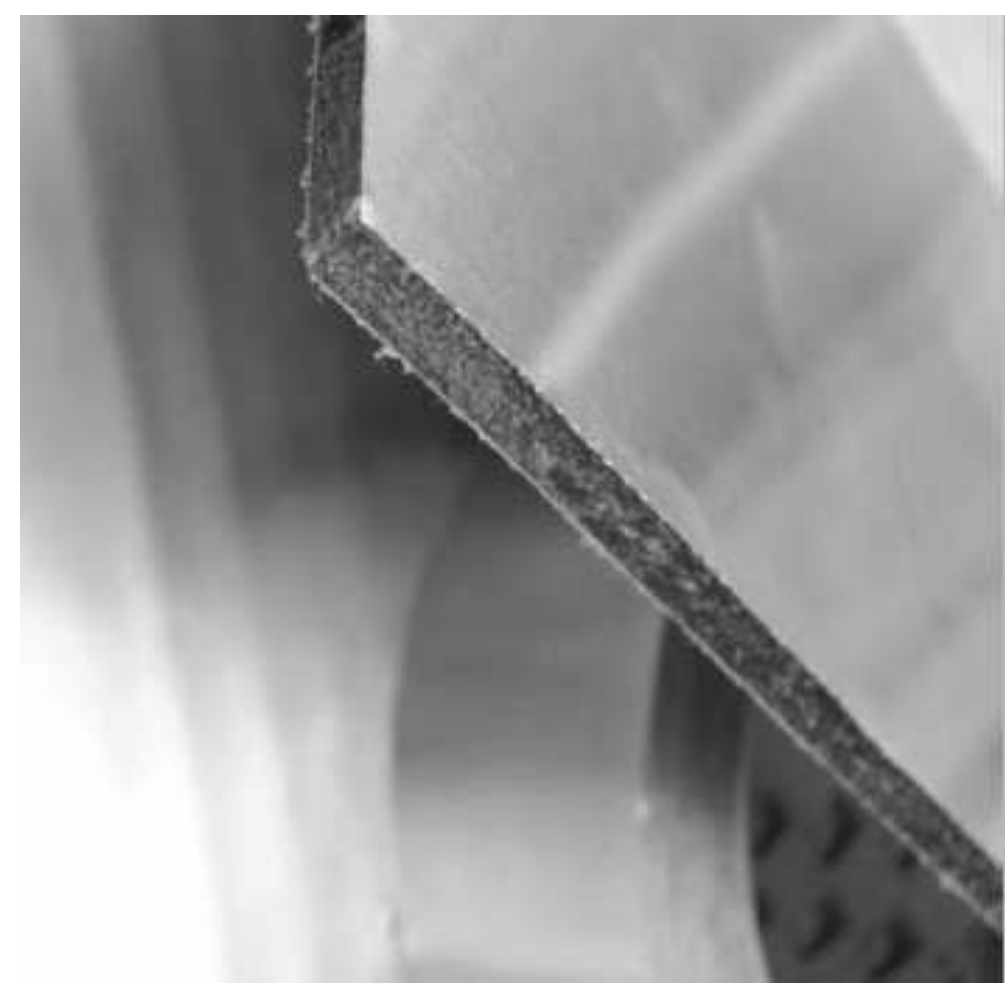

Figure 1: Dupont de Nemours PCM composite wallboard. 


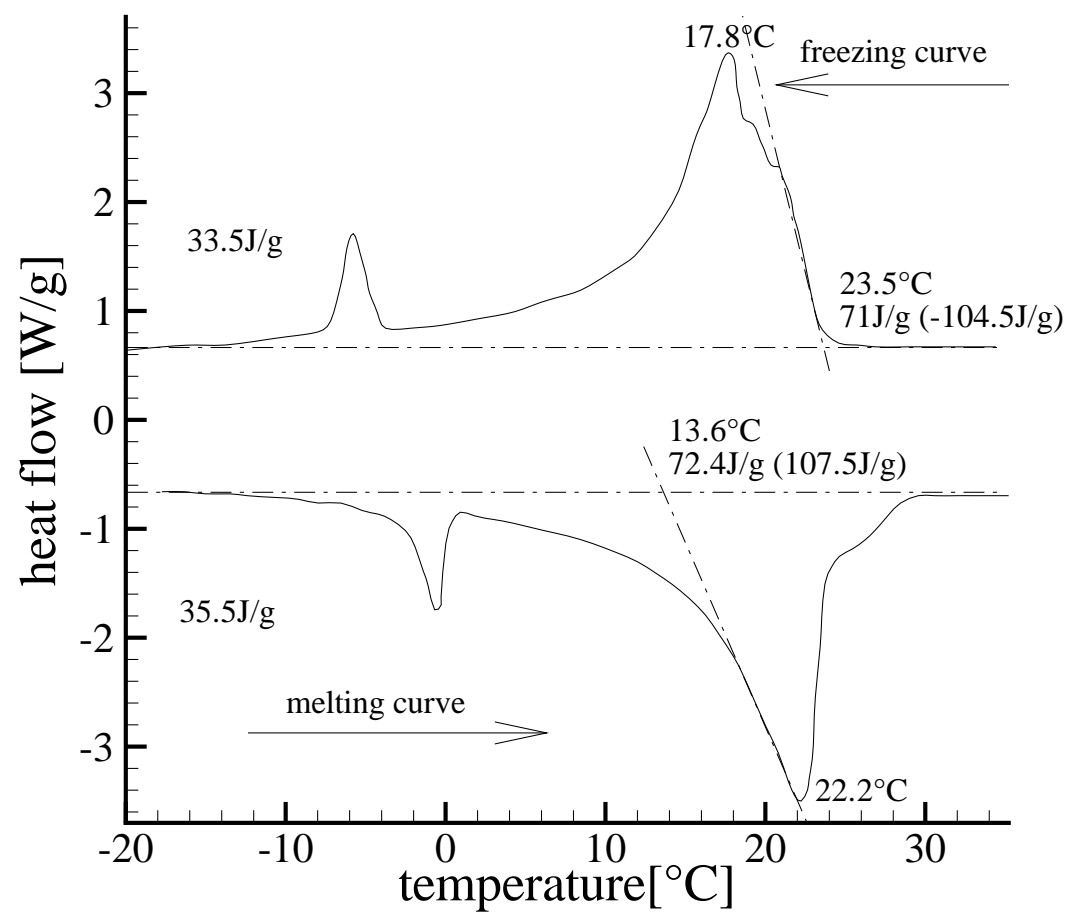

Figure 2: Differential scanning calorimeter melting and freezing curves for the composite PCM. 


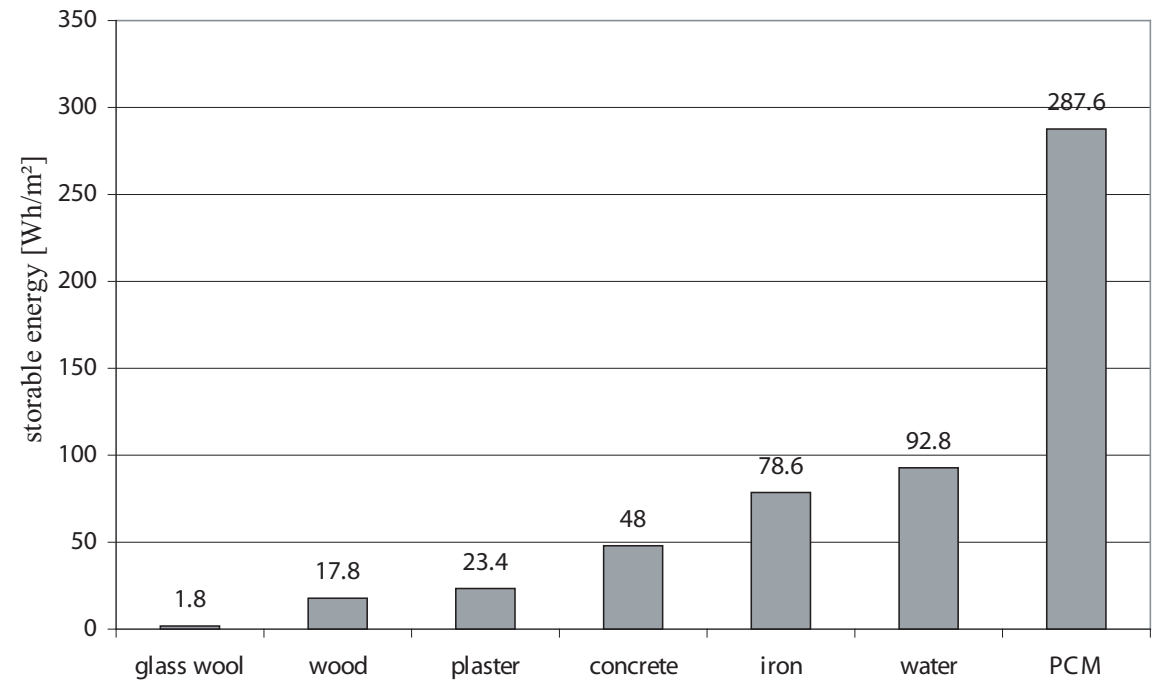

Figure 3: Comparative values storage capacity of building materials in the same conditions of temperature variation and of thickness. 

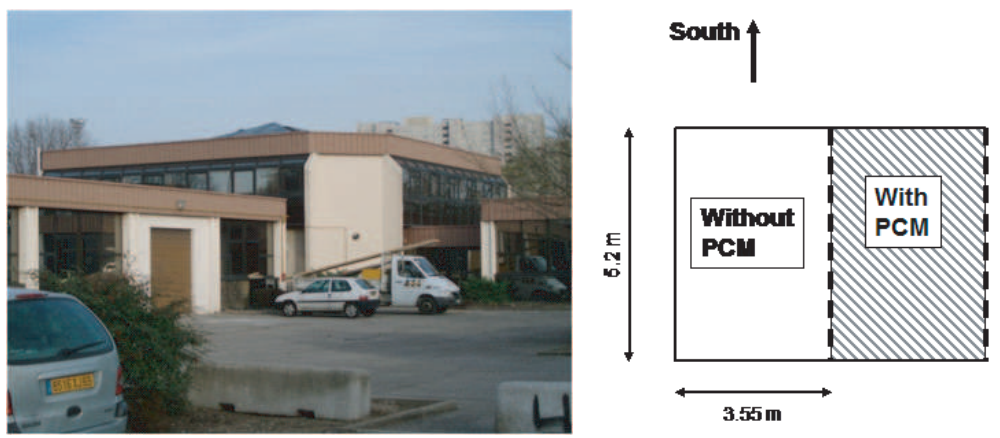

Figure 4: View of the Helios building and the two adjacent monitored rooms. 

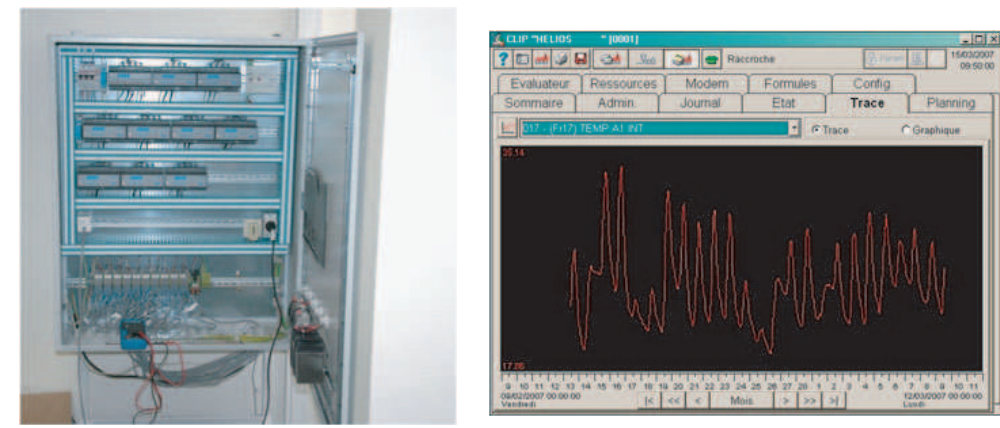

Figure 5: The monitoring system: the acquisition data modules and the monitoring screen. 


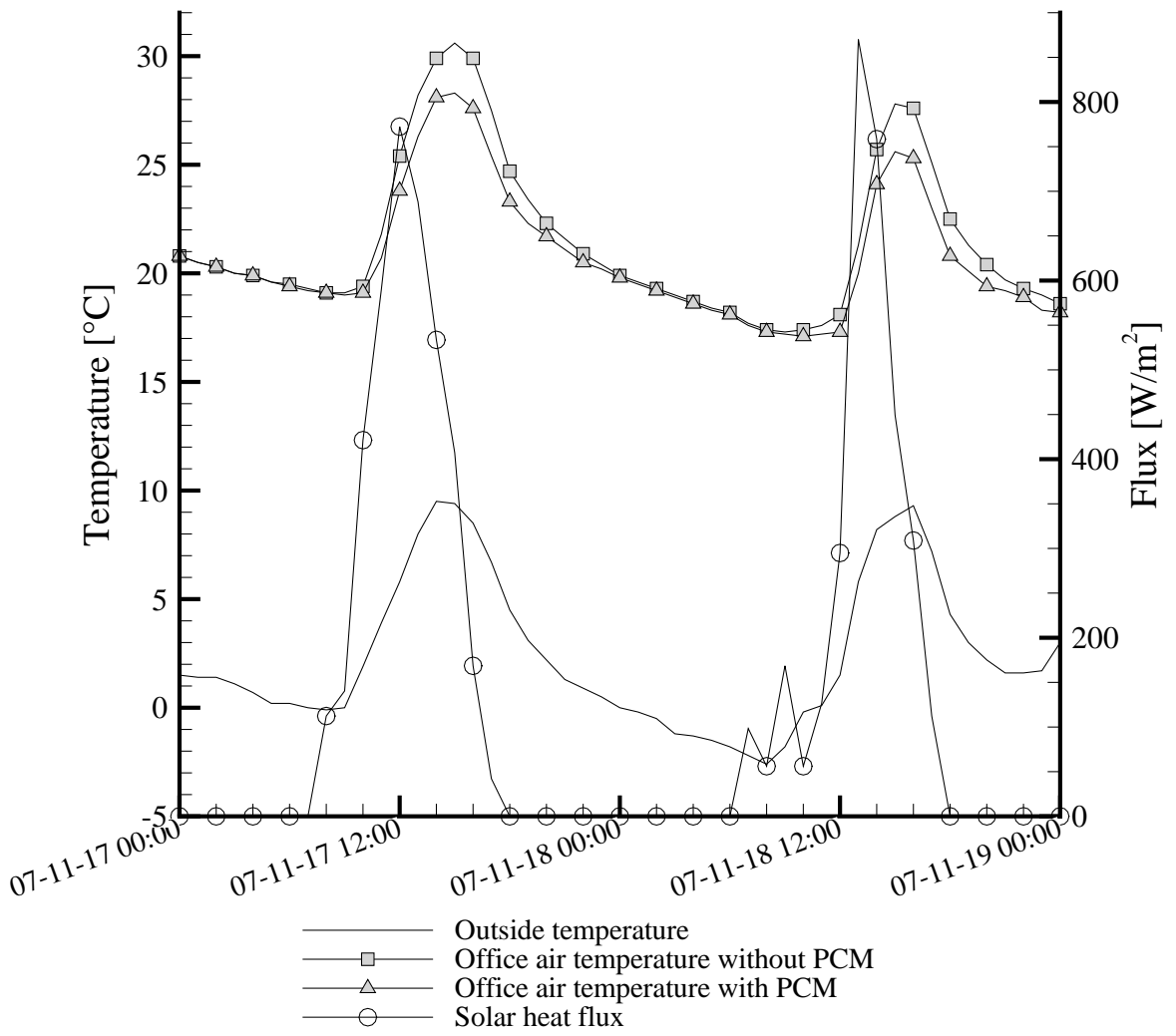

Figure 6: Week-end of November $17^{t h} / 18^{\text {th }}$ 2007. We observe the efficiency of the PCM during day period. Heating system has been stopped during this week-end. 


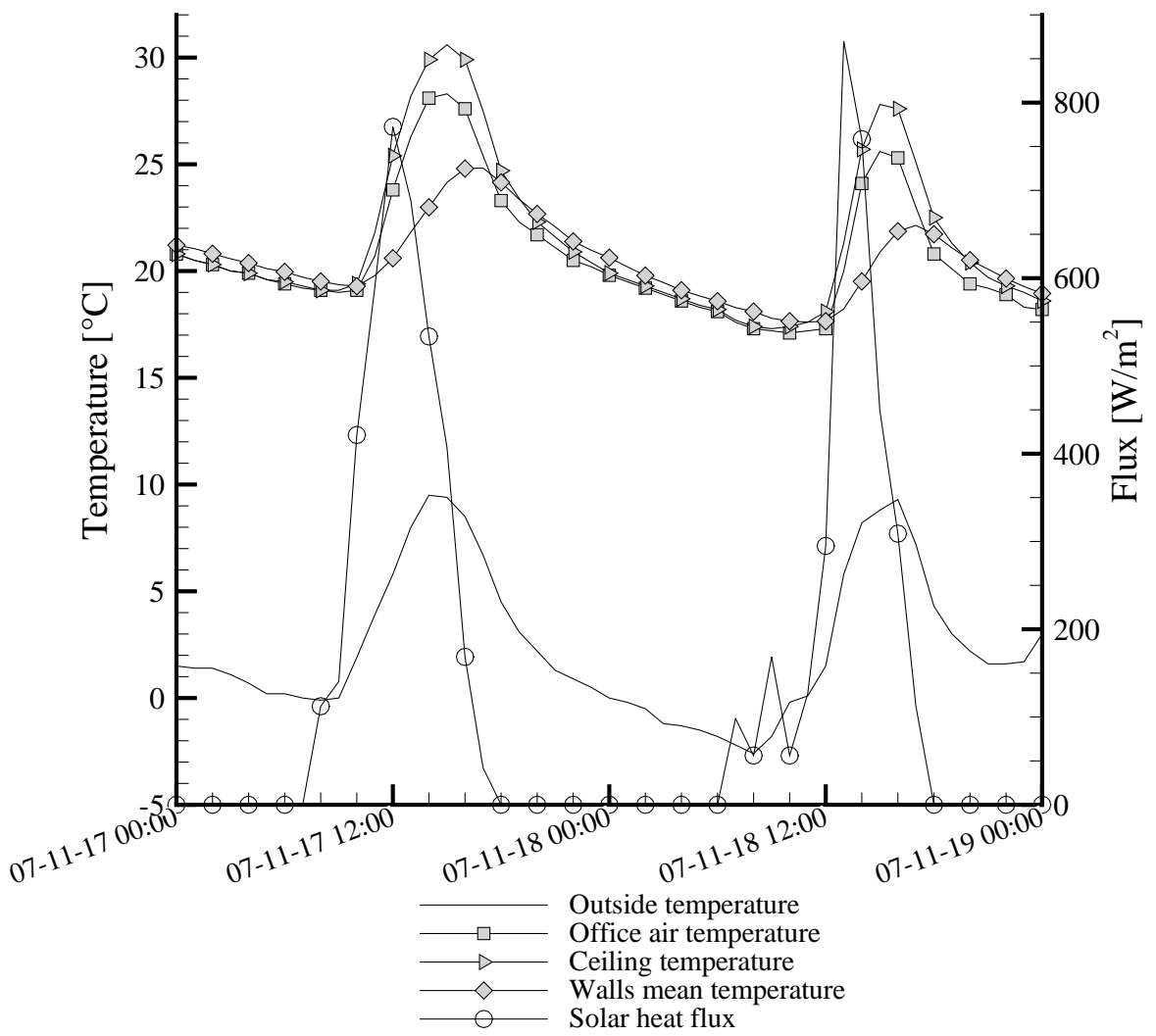

Figure 7: Week-end of November $17^{\text {th }} / 18^{\text {th }}$ 2007. Walls, ceiling and air temperatures for the room without PCM. 


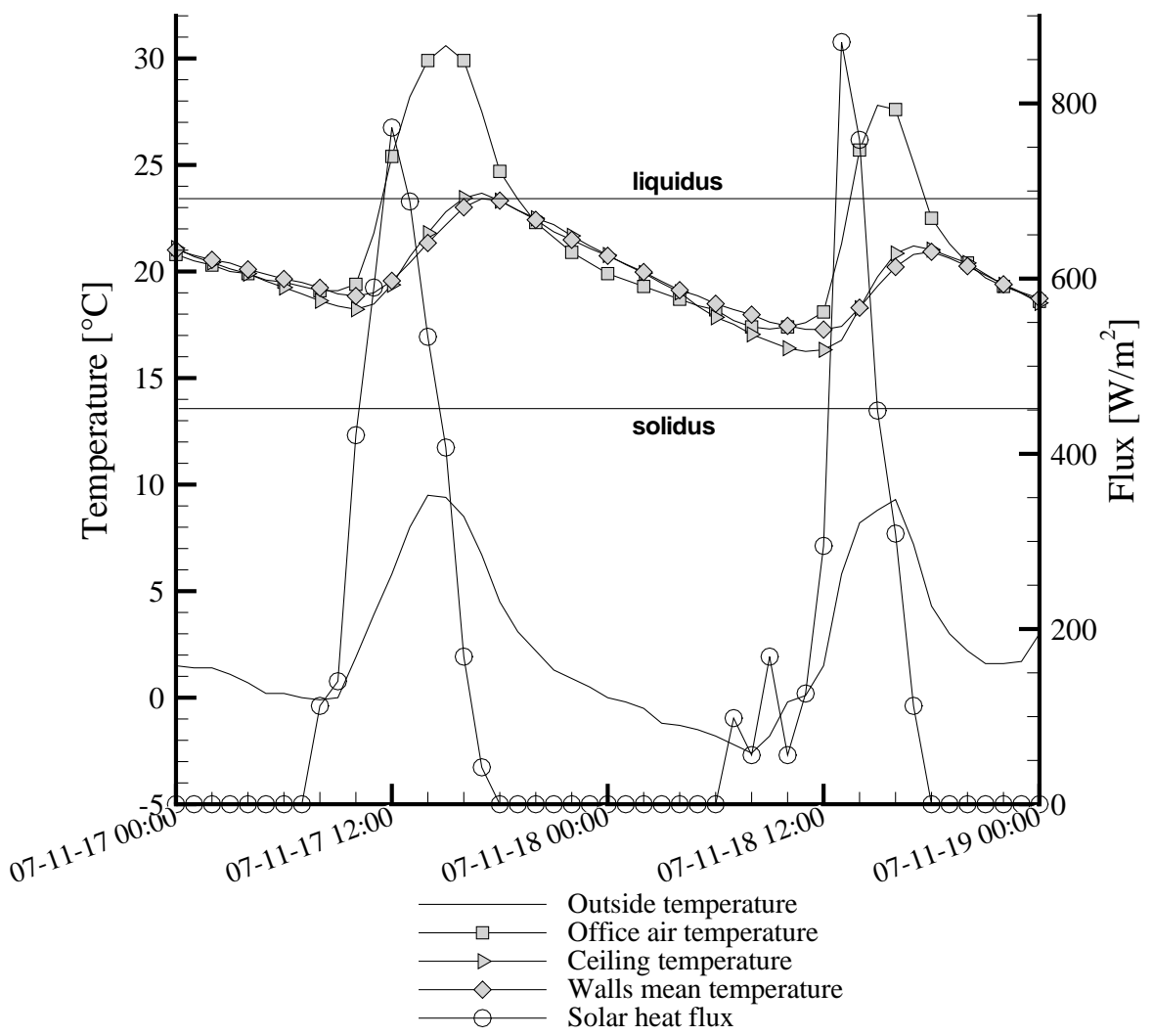

Figure 8: Week-end of November $17^{\text {th }} / 18^{\text {th }} 2007$. Walls, ceiling and air temperatures for the room with PCM. 


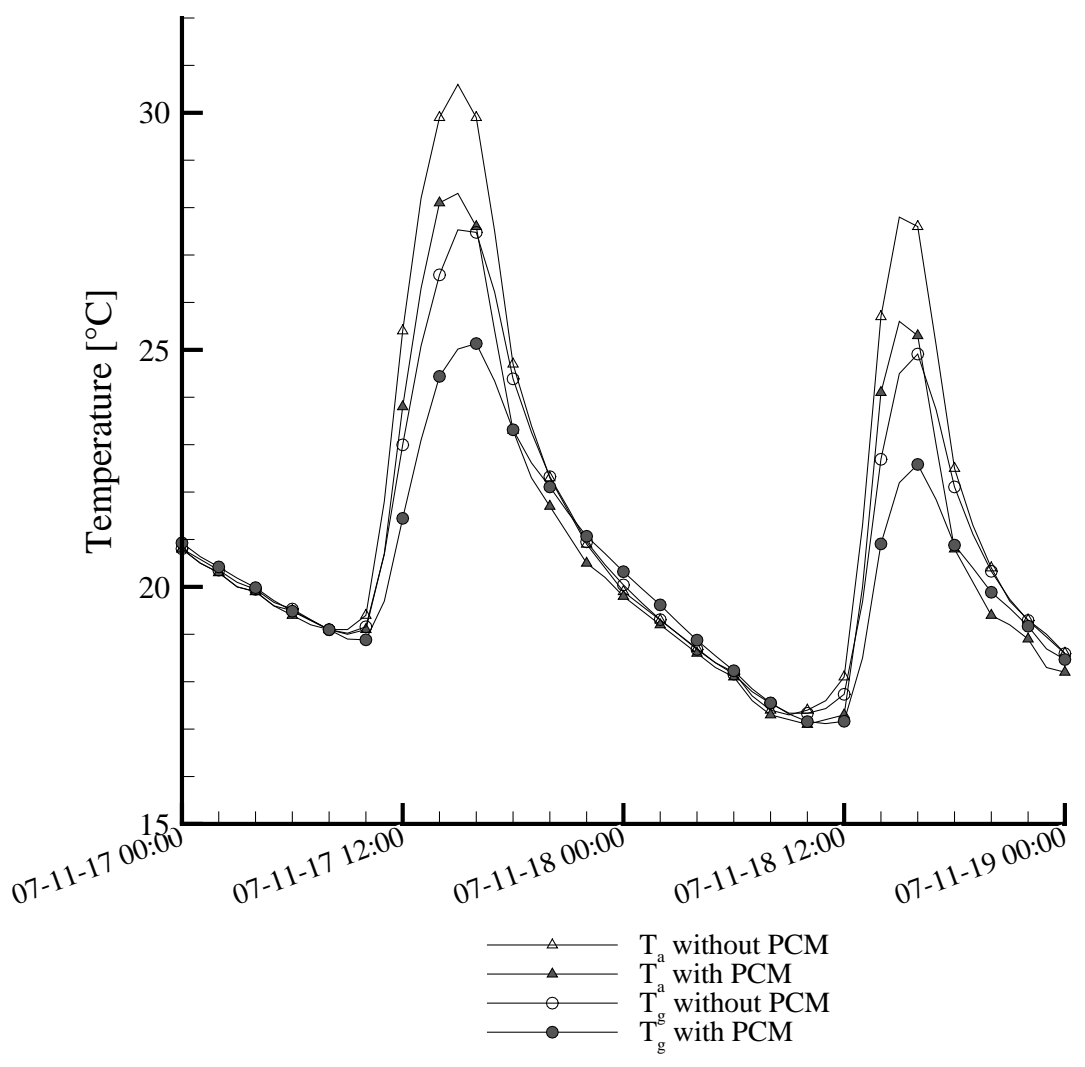

Figure 9: $T_{a}$ and $T_{g}$ evolution on November 17. 


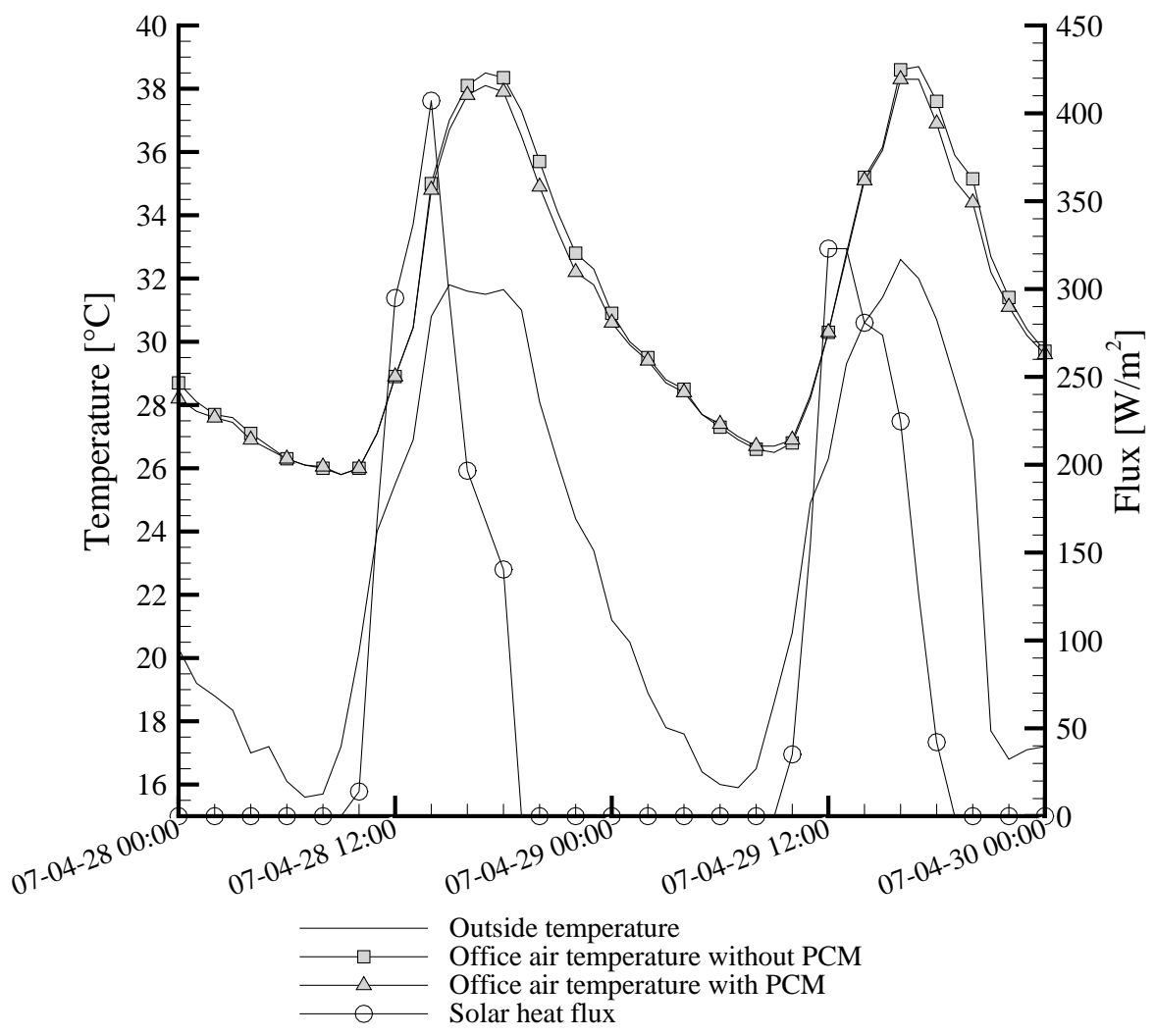

Figure 10: Week-end of March $28^{\text {th }} / 29^{\text {th }}$ 2007. A temperature higher than the freezing temperature is observed and the PCM is not efficient. Heating and cooling systems are off during this mid-season period. 